Pediat. Res. 4: 268-279 (1970)

Adipose tissue lean body mass adolescence muscle

DNA obesity

\title{
Overgrowth of Lean and Adipose Tissues in Adolescent Obesity
}

\author{
Donald B. GheeK ${ }^{[56]}$, Robert B. Sahultz, Adalberto Parra and Richard C. Reba \\ Division of Growth, Children's Medical and Surgical Center, The Johns Hopkins Hospital, \\ Baltimore, Maryland, USA
}

\begin{abstract}
Extract
In 14 obese females and 9 obese males, body length was used as a base line for the detection of excess growth of lean and adipose tissue.

Eighteen patients had increased lean body mass based on body water determinations (fig. 1), and ${ }^{40} \mathrm{~K}$ was found to be an unreliable diagnostic agent for the prediction of lean body mass. A similar number of patients had excessive amounts of intracellular mass (fig. 2). Males had an increment in total protein content within the adipose tissue mass (table IV), whereas half of the females (and all those possessing advanced bone age) had increments in muscle mass (fig. 3) and in the DNA content of their musculature (fig. 4). A sufficient number of female patients were studied to document two classes of obesity-one group with, and one group without advanced maturation, excess nuclei (fig.4), and reduced protein/DNA (fig. 5) in the musculature.

Studies of noncollagen protein in adipose tissue mass of male subjects indicated an increase in the number of adipocytes compared with those found in normal or obese females (table IV). In addition, protein and water concentrations of adipose tissue were reduced in all the obese patients studied (table III). The extracellular volume was found to be constant at $17 \%$ of body weight in obese adolescent males.
\end{abstract}

\section{Speculation}

Obesity in adolescents is the result of genetic, environmental, nutritional, and hormonal factors. Overnutrition in infancy influences hormonal secretion and produces advanced maturation and excessive cell growth in muscle (as found in this study in one group of obese females). Also, in one group of obese females, estrogens, which retard cell number increase (in the normal pubertal female), are possibly suppressed by androgens and thus allow androgen and growth hormone to exert maximal effects at the muscle level (increase of cell number).

In the obese male, the superimposition of high levels of circulating insulin on androgen secretion enhances the growth of collagen and of adipocytes in the adipose tissue mass. Thus, the particular changes in body composition occurring in obesity are dependent on the sex of the individual. 


\section{Introduction}

The problem of obesity is of increasing importance to the affluent society. The incidence in the high school student is reported to be from 10 to $23 \%[5,26,27,30$, $41,46]$.

It is known from animal experiments that overnutrition during infancy leads to overgrowth of lean tissue with advanced bone age $[14,15,50]$, an excess number of adipocytes [28] and of visceral cells [51]. Comprehensive studies on body composition are not available for obese children and adolescents; however, evidence exists that lean body mass is excessive in some adolescent patients with obesity [16, 24, 36]. Some patients are said to have advanced bone age, excess length, and a history of obesity dating from infancy [16]. By contrast, other obese patients have excessive weight due only to excess fat, with normal bone age, body length, and a history of obesity dating from the childhood years.

The present study was undertaken to assess body composition in obesity, to search for evidence of overgrowth with respect to the total cell mass, to evaluate the number of cells or nuclei in muscle, and to obtain information concerning the composition of the adipose tissue mass.

Total body water is a function of the lean body mass while the difference between body water and extracellular water is a direct index of cell mass, since the ratio of cell protein to cell water is constant [11]. Considerable evidence exists [20] that creatinine excretion reflects muscle mass. From analyses of a sample of muscle it is possible to determine the protein and deoxyribonucleic acid content. The number of nuclei present in the entire musculature can be calculated assuming that the sample analyzed is representative of the muscle mass. These considerations are discussed elsewhere [7]. Data for normal children as related to height during growth have been documented [7, 8].

The assessment of 'fatness' in normal or obese children is difficult. Anthropometric charts and considerations of weight for age or weight against height provide a rough measure. Nrcholson and ZiLva [35] assumed that height is directly related to lean body mass and used the ratio wt $/ \mathrm{ht}^{3}$ as an index of 'fatness' in obesity. Radiologic assessments [19, 24, 43], measurements of skinfold thickness [48], or determination of body ${ }^{40} \mathrm{~K}$ or body water have been used $[16,24]$. The latter two techniques depend on the estimate of lean body mass (LBM) and the subtraction of LBM from body weight to estimate body fat. Mellits and CHeEk [33] demonstrated an excellent quadratic relation in normal subjects between body water and height during growth. Furthermore, it is possible to demonstrate quadratic relations between body fat and height for normal males and normal females from 1 to 30 years of age.

These equations are empirical insofar as there is no precise physiologic reason for fatness to relate to length. These relationships, however, do provide a simple means for predicting the normal amount of body fat for height.

The measurement of the number of fat cells in the adipose tissue mass is difficult. Techniques based on fixation of adipocytes with osmium tetroxide [45] may not be completely quantitative.

A simple approach is made here. It is assumed that the collagen in the adipose tissue mass is related exclusively to connective tissue cells, since connective tissue is composed almost entirely of collagen nitrogen [31]. The noncollagen protein is related, therefore, to the adipocyte. Thus, it is considered that the mass of noncollagen protein in the adipose tissue is a measure of adipocyte cell population.

\section{Clinical Material}

Fourteen obese females and nine obese males were investigated [53]. Four of the obese patients had a family history of diabetes mellitus, while one girl $\left(O_{48}\right)$ was found to have the disease at the time of study. All except four patients $\left(O_{41}, O_{50}, O_{55}\right.$, and $\left.O_{62}\right)$ had a family history of obesity. Of the obese girls, seven were less than 11 years of age, the other seven ranged from 12 to 17 years. Five of these subjects had a history of irregular menstruation.

\section{Methods}

The age of onset of obesity was determined by inspection of family photographs or from weight records kept by the family ( $90 \%$ of instances). Methods for the determination of extracellular volume (corrected bromide space or EGV) have been given elsewhere [11] while body potassium was measured by ${ }^{40} \mathrm{~K}$ counting [42]. For the measurement of muscle mass (MM), three 24-hour urine specimens were collected while the patient was on a low creatinine diet. For reasons explained elsewhere [20], it is considered that each gram of creatinine excreted per day is equivalent to $20 \mathrm{~kg}$ of MM.

A small sample of muscle was taken from the gluteal region of most patients as described previously [47]. The protein/DNA ratio of muscle was taken as an assessment of muscle cell size while the number of nuclei in the muscle mass was calculated:

$$
\text { grams of muscle mass } \times \frac{\text { DNA per gram }}{\text { DNA per nucleus }}
$$


as explained elsewhere $[7,8]$. The data concerning obese children have been compared with published data for normal adolescents $[7,13]$.

Deuterium oxide was used for the determination of body water (TW) as described previously [7]. Lean body mass was estimated by the use of the Pace constant (0.72):

$$
\mathrm{LBM}=\frac{\mathrm{TW}}{0.72}
$$

Intracellular (ICW) water was determined as the difference between TW and ECV and since the ratio of protein to water is constant within the cell, intracellular water $(67 \%)$ predicts intracellular mass. Muscle and visceral cells and, to a lesser extent, connective tissue cells all constitute the intracellular mass.

Body fat was taken as the weight minus lean body mass. By applying equations [33] to predict expected fat for length for a particular subject and subtracting this quantity from body fat (as found from body water studies) it was possible to predict 'excess fatness'.

Methods for determination of collagen, protein, fat, and water in a sample of adipose tissue (which was removed from the gluteal region) are similar to those reported previously $[7,21]$. Since the percentage of fat, water, collagen, and noncollagen protein was determined in the adipose tissue sample it was possible to determine the total adipose tissue mass, provided the sample was representative of the adipose tissue as a whole.

Total adipose mass, in $\mathrm{kg}=\frac{\text { total body fat, } \mathrm{kg} \times 100}{\% \text { fat in adipose sample }}$

The amount of noncollagen protein present in the adipose tissue mass is given by:

total adipose mass $\times$ percentage noncollagen protein 100

Bone age was determined by the methods of GreuLICH and PyLE [22] and GARN et al. [18]. The work of GARN and his colleagues showed that in predicting skeletal maturation the time of appearance of the epiphyses of the phalanges and metacarpals is more reliable than the appearance time of the carpal bones and of the distal radial and ulnar epiphyses. Consequently, the latter centers were ignored in determining skeletal maturation except in boys 17 years of age or older and in girls 15 years of age or older, when other criteria were not available. Standards adopted by the Brush Foundation for the normal variability of skeletal age of boys and girls were accepted (tables III and IV in GREULICH [22]). If the bone age was greater than two standard deviations above the mean it was considered advanced.

Subject $O_{57}$ presented as a special case since her epiphyses had already fused. This corresponds to a bone age in the female of 18 years or older. Her chronological age was 17 years and she was on the 10 th percentile for height. It was concluded that she had advanced maturation and bone age which was responsible for the early epiphyseal closure and reduced height, as seen in precocious puberty; however, definitive proof was not available.

\section{Results}

\section{Anthropometric and Skeletal Data}

Data for age, bone age, height, weight, and percentile ratings for the obese patients are shown in table $\mathrm{I}$. An estimate of the age of onset of obesity is given. Of the 11 females assessed for bone age 5 had advanced values $\left(\mathrm{O}_{48}, \mathrm{O}_{50}, \mathrm{O}_{57}, \mathrm{O}_{58}\right.$, and $\left.O_{60}\right)$ while 2 $\left(O_{49}\right.$ and $\left.O_{61}\right)$ were advanced only 1 year. Two boys $\left(O_{47}\right.$ and $\left.O_{53}\right)$ had advanced bone age, two did not, and five others were not investigated.

Female subjects $O_{49}, O_{50}, O_{52}, O_{55}$, and $O_{59}$ had birth weights that fell above the 90 th percentile at 40 weeks gestation as defined by BATTAGLIA and LuBcHENCO [3]. Information concerning birth weights was available for five males. Three $\left(O_{47}, O_{51}\right.$, and $\left.O_{53}\right)$ had high birth weights. Two boys with advanced bone age $\left(O_{47}\right.$ and $\left.\mathrm{O}_{53}\right)$ had high birth weights whereas only one girl with advanced bone age $\left(O_{50}\right)$ had this finding.

At the time of this study, all patients had gross excess weight for age. For males the values ranged from 55 to $196 \mathrm{~kg}$, and for females 47 to $127 \mathrm{~kg}$. For age, all patients were beyond the 97 th percentile. With respect to length, five of the nine males had points which fell at or beyond the 90th percentile, while the value for patient $O_{43}$ fell on the 10 th percentile. For six girls, the values were at or beyond the 90 th percentile while the point for patient $O_{57}$ fell on the 10th percentile.

\section{Lean Body Mass}

Table I also contains data concerning lean body mass, body water, extracellular water and, by difference, intracellular water. Total body $\mathrm{K}$ from ${ }^{40} \mathrm{~K}$ measurements is recorded.

In figure 1, data for total body water are plotted against length. In previous work [32] it has been shown that the relation between body water and length during growth for each sex could be defined as a quadratic equation. With the use of a computer a quadratic equation can be expressed as two intersecting lines with an upper and lower segment. In figure 1, the upper segments are shown for normal boys and girls of the same age range as the obese adolescents. The points for the obese boys fell two standard deviations beyond the normal population. Three of the obese girls had values that can be regarded as normal for length, while the tallest girl $\left(O_{45}\right)$ had a value that was low (if the normal line is extended). It will be recalled 
Overgrowth of lean and adipose tissues in adolescent obesity

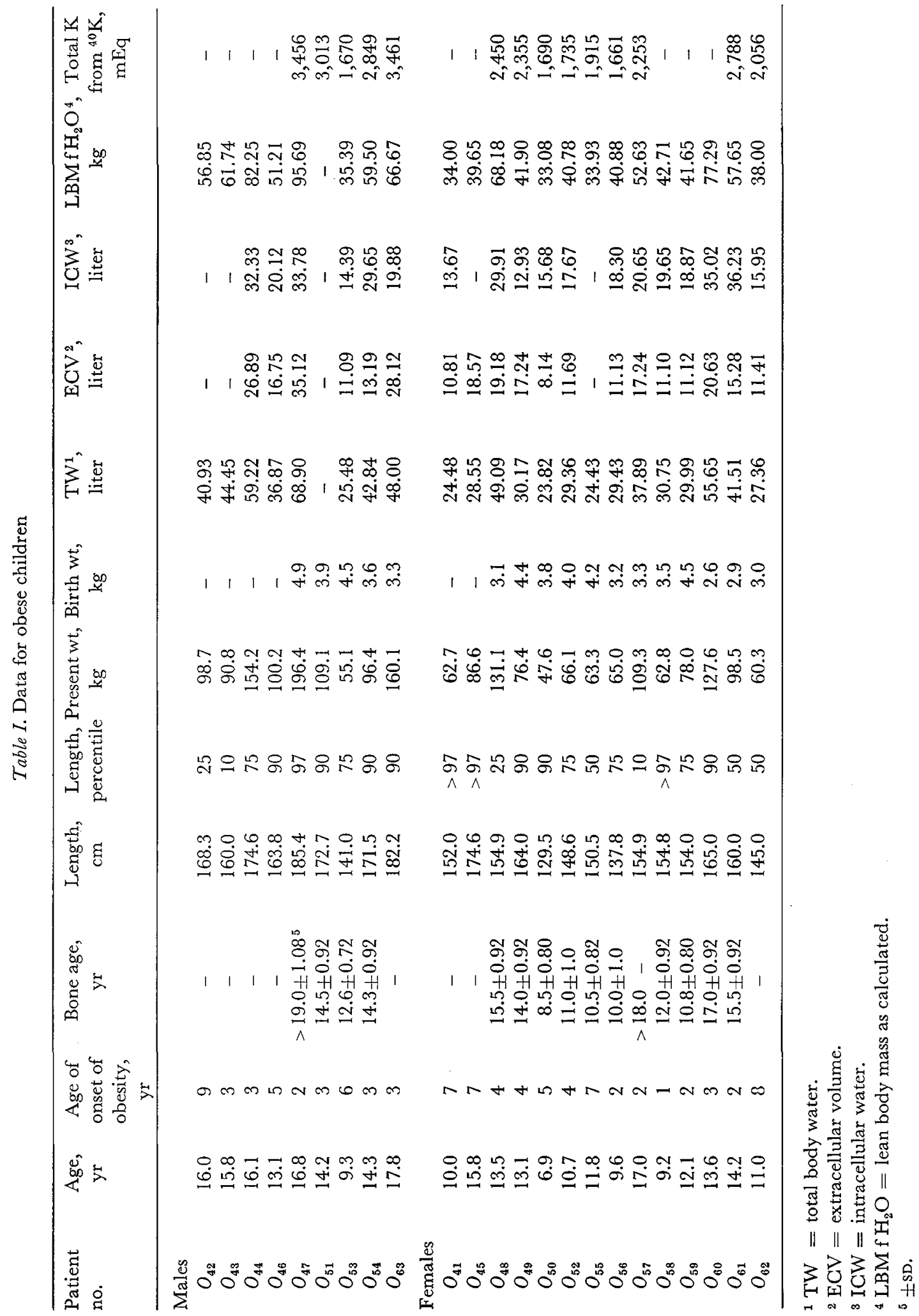


that TW/0.72 predicts lean body mass; hence, an excess of lean body mass for length was demonstrated in 18 of 22 subjects.

The application of ${ }^{40} \mathrm{~K}$ counting for assessment of lean body mass was unsatisfactory in the obese patients. The relation between body $\mathrm{K}$ and $\mathrm{TW}$ for obese girls (for example) was as follows:

$$
\mathrm{K}, \mathrm{mEq}=971.29+34.673(\mathrm{TW})
$$

For normal girls of lesser weight but the same age range the relation was:

$$
\mathrm{K}, \mathrm{mEq}=145.98+67.663(\mathrm{TW})
$$

Analysis of covariance demonstrated that these lines were derived from two different populations. The slopes of the lines were different $(P<0.01)$. If the line for normal girls was extended into the range for total water of obese girls it was clear that body potassium for obese girls was less than expected. Similarly, if the few points obtained for obese boys were plotted on the graph for normal boys the points fell below the line. Injection of small amounts of ${ }^{42} \mathrm{~K}$ into the obese subjects did not allow a better prediction of lean body mass.

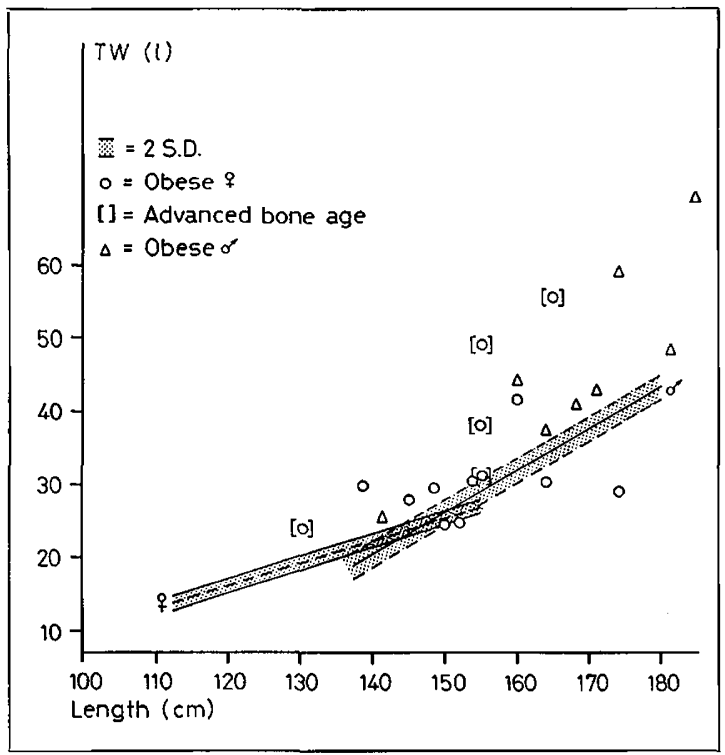

Fig. 1. Relation of body water to body length for normal adolescent boys and girls $( \pm 2 \mathrm{sD})$; the two linear relations are discussed elsewhere [32]. Points for obese girls (with and without advanced bone age) and for obese boys are plotted. In almost all instances a large increase in body water or lean body mass for length was noted.

\section{Intracellular Phase}

In figure 2 the relation between intracellular water and length for normal boys and girls is quadratic. The values for four of six obese boys fell above the values for normal boys of the same length. Similarly, 10 of 12 values for obese girls-and including all patients possessing advanced bone age-fell above the shaded area or above two standard deviations from the normal line. The other two points fell below the normal line and one below the shaded area.

The point for the tallest girl (subject $O_{45}$ ) was not recorded since measurements of intra- or extracellular water were not made simultaneously. The value for ICW, however, must have been of the order of 10 liters, which in turn would be a low value for length.

Thus, the majority of subjects demonstrated an increase in ICW. Since the ratio of cell protein to cell water is constant, one can conclude that the intracellular mass of the body is increased relative to length for most of the obese individuals studied.

\section{Muscle Mass}

When a similar plot was made of muscle mass against height (fig. 3 ) it was found that points for obese boys



Fig.2. Relation of intracellular water (a fraction of intracellular mass) to length of adolescent boys and girls. Four of six points for obese boys fall above $2 \mathrm{sD}$ and all except two points fall above $2 \mathrm{sD}$ for obese girls. Points for girls possessing advanced bone age are identified. 




Fig.3. Muscle mass measured in kilograms during adolescent growth. Points for obese boys fall slightly below the normal curve. Seven female patients have excessive muscle mass for length including all patients with advanced bone age. Two standard deviations around the lines are defined.

followed the normal curve. By contrast, seven obese girls had points that fell above two standard deviations from the normal population $\left(\mathrm{O}_{48}, \mathrm{O}_{50}, \mathrm{O}_{55}, \mathrm{O}_{57}, \mathrm{O}_{58}\right.$, $O_{59}$, and $\left.O_{60}\right)$. Five of these subjects had advanced bone age $\left(O_{48}, O_{50}, O_{57}, O_{58}\right.$, and $\left.O_{60}\right)$. Five other girls had points that fell within two standard deviations of the normal. Thus, more than one-half the girls but none of the boys had excess muscle mass in relation to length.

\section{Size and Number of Muscle Celis}

Table II shows the data relating to studies on muscle cell growth. Figure 4 illustrates the relation between number of nuclei in the musculature and length. The points for four of five obese male patients followed the normal curve, but three of the points fell at a higher level and were commensurate with the excess height. Gertain obese female patients, however, demonstrated a gross departure from normal and an excess number of nuclei for length. These obese girls all had advanced bone age.

In figure 5 the protein/DNA ratios (cell size) are shown in the muscle for the obese patients. Muscle mass forms the abcissa. All the girls with advanced bone age had a reduction in the size of their muscle cells. Two girls $\left(O_{49}\right.$ and $\left.O_{61}\right)$ with an advanced bone age of only 1 year also showed the same finding.

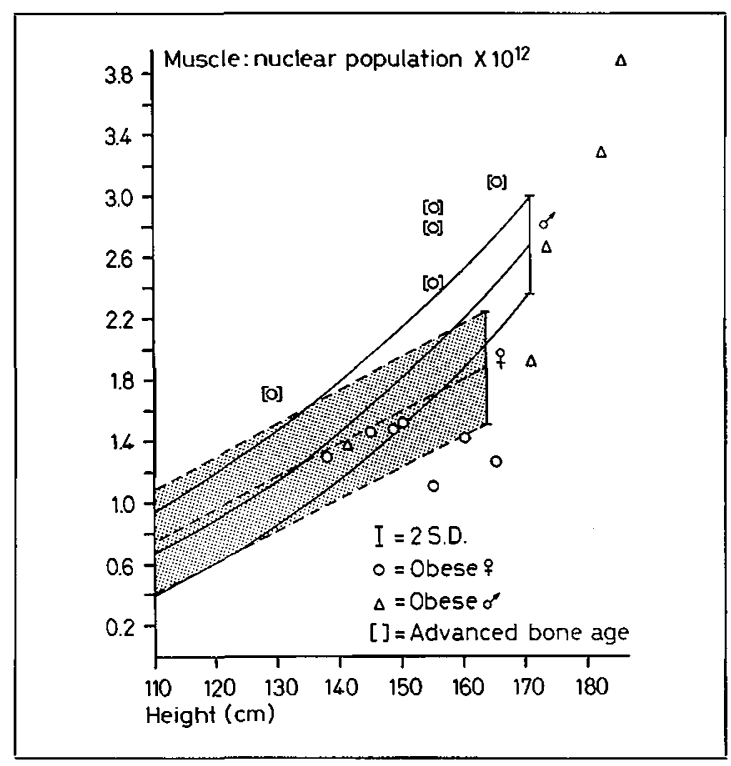

Fig.4. Normal relation for number of nuclei in the musculature during adolescent growth when length is the base line. Three of five points for obese boys fall close to the extension of the normal line, while a fourth point falls close to the normal line. Girls with advanced bone age, however, have points that fall well above the normal linear relation for girls.



Fig. 5. Muscle cell size for normal boys and girls during adolescence. The relations are quadratic when body size (or muscle mass) forms the base line. Solid line represents the relation for boys and dashed line the relation for girls. Seven obese girls, including those with advanced bone age, have reduction in muscle cell size. 
Adipose Tissue and Body Fat

Table III contains data concerning total body fat, expected fat for length, and the difference between the two measurements, expressed as 'excess fat'. The 'excess fat' in males ranges from 15 to $89 \mathrm{~kg}$ and in females from 9 to $45 \mathrm{~kg}$. In addition, direct analyses of the adipose tissue are recorded. The overall percentage of fat in adipose tissue was $69-92 \%$; collagen, protein, and water made up the remainder. Data concerning only four normal subjects are presented but the percentage of protein, collagen, and noncollagen protein in a fresh sample of adipose tissue was reduced significantly ir obese children $(P<0.005)$. More analyses for normal children are needed. Our normal data are in agreement with those of BAKER [2].

In table IV, mean values have been recorded for the assessment of total adipose tissue mass for obese subjects and for normal subjects. Similarly, the total amount of collagen and noncollagen protein in the adipose mass are recorded. Obese males have more excess adipose tissue than females. Females, however, irrespective of 'fatness' appear to have the same total amount of collagen and noncollagen protein within the adipose tissue. Obese males have larger amounts of total collagen and noncollagen protein relative to normal males. These findings indicate that an excessive amount of lean tissue is present in the adipose tissue mass for obese boys. A large increase in adipocyte cell population is predicted provided that noncollagen protein reflects cell number in adipose tissue.

\section{ECV and Body Weight}

Of interest was the finding that in obese males the ECV remained between 16.0 and $17.5 \%$ of body weight (which in turn ranged from 55 to $200 \mathrm{~kg}$ ). The relation was given by the following equation:

$$
\begin{aligned}
\mathrm{EGV} & =0.181 \mathrm{wt}-1.154 \\
\mathrm{SD} & =1.6 \text { liters } \\
r & =0.98
\end{aligned}
$$

The EGV would vary from 24.4 to $23.2 \%$ of body weight if normal boys were of the same weight range. Obese girls (47-120 kg) also showed reduced EGV in

\begin{tabular}{|c|c|c|c|c|c|c|c|c|c|}
\hline $\begin{array}{l}\text { Patient } \\
\text { no. }\end{array}$ & $\begin{array}{l}\text { Chron- } \\
\text { ological } \\
\text { age, yr }\end{array}$ & $\begin{array}{l}\text { Length, } \\
\mathrm{cm}\end{array}$ & $\begin{array}{l}\mathrm{Wt} \\
\mathrm{kg}\end{array}$ & $\begin{array}{l}\mathrm{MM}^{1} \\
\mathrm{~kg}\end{array}$ & $\begin{array}{c}\mathrm{CNG}^{2} \\
\times 10^{9}\end{array}$ & $\begin{array}{c}\mathrm{MCP}^{3} \\
\times 10^{12}\end{array}$ & $\begin{array}{c}\text { DNA, } \\
\mathrm{mg} / \mathrm{g} \\
\text { FFFM }^{4}\end{array}$ & $\begin{array}{l}\text { Protein, } \\
\mathrm{mg} / \mathrm{g} \\
\text { FFFM }^{4}\end{array}$ & $\begin{array}{c}\text { Protein/ } \\
\text { DNA } \\
\text { ratio }\end{array}$ \\
\hline \multicolumn{10}{|l|}{ Males } \\
\hline$O_{47}$ & 16.8 & 185.4 & 196.4 & 30.20 & 0.131 & 3.956 & 0.812 & 199 & 245.1 \\
\hline$O_{51}$ & 14.2 & 172.7 & 109.1 & 25.56 & 0.105 & 2.684 & 0.649 & 186 & 286.6 \\
\hline$O_{53}$ & 9.3 & 141.0 & 55.1 & 11.60 & 0.120 & 1.392 & 0.744 & 196 & 263.4 \\
\hline$O_{54}$ & 14.3 & 171.5 & 96.4 & 21.86 & 0.088 & 1.924 & 0.546 & 188 & 344.3 \\
\hline$O_{63}$ & 17.8 & 182.2 & 160.1 & 29.68 & 0.111 & 3.294 & 0.687 & 195 & 283.8 \\
\hline \multicolumn{10}{|l|}{ Females } \\
\hline$O_{48}$ & 13.5 & 154.9 & 131.1 & 26.44 & 0.111 & 2.935 & 0.690 & 187 & 271.0 \\
\hline$O_{49}$ & 13.1 & 164.0 & 76.4 & 20.82 & 0.105 & 2.186 & 0.653 & 173 & 264.9 \\
\hline$O_{50}$ & 6.9 & 129.5 & 47.6 & 12.36 & 0.138 & 1.706 & 0.855 & 192 & 224.6 \\
\hline$O_{52}$ & 10.7 & 148.6 & 66.1 & 14.18 & 0.105 & 1.489 & 0.652 & 198 & 303.7 \\
\hline$O_{55}$ & 11.8 & 150.5 & 63.3 & 17.46 & 0.083 & 1.536 & 0.544 & 192 & 352.9 \\
\hline$O_{56}$ & 9.6 & 137.8 & 65.0 & 11.52 & 0.114 & 1.313 & 0.706 & 202 & 286.1 \\
\hline$O_{57}$ & 17.0 & 154.9 & 109.3 & 21.70 & 0.113 & 2.452 & 0.699 & 191 & 273.2 \\
\hline$O_{58}$ & 9.2 & 154.8 & 62.8 & 19.42 & 0.145 & 2.816 & 0.899 & 197 & 219.1 \\
\hline$O_{59}$ & 12.1 & 154.0 & 78.0 & 20.62 & - & - & - & - & - \\
\hline$O_{60}$ & 13.6 & 165.0 & 127.6 & 22.08 & 0.141 & 3.113 & 0.876 & 205 & 234.0 \\
\hline$O_{61}$ & 14.2 & 160.0 & 98.5 & 15.38 & 0.094 & 1.446 & 0.586 & 146 & 249.1 \\
\hline$O_{62}$ & 11.0 & 145.0 & 60.3 & 12.66 & 0.118 & 1.494 & 0.733 & 195 & 266.0 \\
\hline
\end{tabular}
relation to weight $(19.8-15.7 \%)$.

Table II. Muscle mass, number of nuclei and ratio of protein to DNA

I $\mathrm{MM}=$ muscle mass.

${ }^{2} \mathrm{CNG}=$ cell number per gram of muscle.

${ }^{3} \mathrm{MGP}=$ muscle cell population (or number of nuclei).

${ }^{4}$ FFFM $=$ fat-free fresh muscle. 
These findings suggest that excess weight due to excess adipose tissue is accompanied by a proportional increase in extracellular fluid within the adipose tissue mass.

\section{Discussion}

This work reports the overgrowth of tissues that occurs in obesity. More than one-half of the obese females and all but two of the male patients had excessive length for age.

Eighteen of 22 patients studied had excess lean body mass relative to length and a similar proportion had increased intracellular mass. The intracellular mass as measured here includes muscle, viscera, and, to a lesser extent, connective tissue. Further investigation revealed sex differences. Excess growth of lean tissue within the adipose tissue mass could be demon-

Table III. Total body fat, expected fat calculated from length, and difference, expressed as excess fat

\begin{tabular}{|c|c|c|c|c|c|c|c|c|c|c|}
\hline \multirow{3}{*}{$\begin{array}{l}\text { Patient } \\
\text { no. }\end{array}$} & \multirow{3}{*}{$\begin{array}{l}\text { Chron- } \\
\text { ological } \\
\text { age, yr }\end{array}$} & \multicolumn{3}{|c|}{ Body fat } & \multicolumn{6}{|c|}{ Composition of adipose tissue (fresh tissue) } \\
\hline & & Total & Expected & Excess & $\mathrm{H}_{2} \mathrm{O}$ & Fat, & $\mathrm{FFDS}^{3}$, & Protein, & Collage & $\mathrm{NGP}^{4}$, \\
\hline & & fat, $\mathrm{kg}$ & $\mathrm{fat}^{\mathbf{1}}, \mathrm{kg}$ & fat $^{2}, \mathrm{~kg}$ & $\%$ & $\%$ & $\%$ & $\%$ & $\%$ & $\%$ \\
\hline \multicolumn{11}{|l|}{ Males } \\
\hline$O_{42}$ & 16.0 & 41.9 & 8.2 & 33.6 & & & & & & \\
\hline$O_{43}$ & 15.8 & 29.1 & 6.9 & 22.2 & & & & & & \\
\hline$O_{44}$ & 16.1 & 72.0 & 9.3 & 62.6 & & & & & & \\
\hline$O_{46}$ & 13.1 & 49.0 & 7.5 & 41.5 & & & & & & \\
\hline$O_{47}$ & 16.8 & 100.7 & 11.4 & 89.3 & 15.33 & 82.63 & 2.00 & 1.84 & 0.94 & 0.90 \\
\hline$O_{51}$ & 14.2 & - & - & - & 13.34 & 82.48 & 4.18 & 3.20 & 2.17 & 1.03 \\
\hline$O_{53}$ & 9.3 & 19.7 & 4.5 & 15.2 & 10.19 & 87.11 & 2.70 & 1.69 & 0.66 & 1.03 \\
\hline$O_{54}$ & 14.3 & 36.9 & 8.8 & 28.1 & 7.46 & 90.11 & 2.44 & 1.37 & 0.41 & 0.96 \\
\hline$O_{63}$ & 17.8 & 93.4 & 10.8 & 82.6 & & & & & & \\
\hline Mean & & 55.3 & 8.4 & 48.2 & 11.58 & 85.58 & 2.83 & 2.03 & 1.05 & 0.98 \\
\hline SD & & 30.0 & 2.2 & 29.0 & 3.46 & 3.70 & 0.95 & 0.81 & 0.78 & 0.63 \\
\hline \multicolumn{11}{|l|}{ Females } \\
\hline$O_{41}$ & 10.0 & 28.7 & 10.2 & 18.5 & 13.01 & 83.16 & 3.84 & - & - & - . \\
\hline$O_{45}$ & 15.8 & 46.9 & 18.6 & 28.3 & - & - & - & - & - & - \\
\hline$O_{48}$ & 13.5 & 62.9 & 11.1 & 51.8 & 9.97 & 86.98 & 2.98 & 2.40 & 1.06 & 1.34 \\
\hline$O_{49}$ & 13.1 & 34.5 & 14.3 & 20.2 & 13.86 & 82.75 & 3.39 & 2.35 & 0.74 & 1.61 \\
\hline$O_{50}$ & 6.9 & 14.5 & 4.6 & 9.9 & 10.07 & 86.21 & 3.72 & 2.93 & 0.71 & 2.22 \\
\hline $\mathrm{O}_{52}$ & 10.7 & 25.3 & 9.2 & 16.1 & 6.87 & 91.38 & 1.75 & 1.13 & 0.29 & 0.84 \\
\hline$O_{55}$ & 11.8 & 29.4 & 9.8 & 19.6 & 10.57 & 86.27 & 3.15 & 2.78 & 0.91 & 1.87 \\
\hline$O_{56}$ & 9.6 & 24.1 & 6.4 & 17.8 & 12.35 & 84.02 & 3.62 & 3.18 & 1.15 & 2.03 \\
\hline$O_{57}$ & 17.0 & 56.7 & 11.1 & 45.5 & 16.52 & 79.50 & 3.98 & 3.48 & 1.06 & 2.42 \\
\hline$O_{58}$ & 9.2 & 20.1 & 11.1 & 9.0 & 7.65 & 89.90 & 2.45 & 1.77 & 0.64 & 1.13 \\
\hline$O_{59}$ & 12.1 & 36.4 & 10.8 & 25.5 & 13.02 & 85.49 & 1.49 & 1.17 & 0.36 & 0.81 \\
\hline$O_{60}$ & 13.5 & 50.3 & 14.7 & 35.6 & 9.99 & 86.85 & 3.15 & 2.76 & 0.63 & 2.13 \\
\hline$O_{61}$ & 14.2 & 40.9 & 12.96 & 28.0 & 6.59 & 91.53 & 1.87 & 1.41 & 0.28 & 1.13 \\
\hline$O_{62}$ & 11.0 & 22.3 & 11.6 & 10.7 & 28.38 & 69.31 & 2.31 & 1.87 & 0.70 & 1.16 \\
\hline Mean & & 35.2 & 11.2 & 24.0 & 12.22 & 84.87 & 2.90 & 2.27 & 0.71 & 1.08 \\
\hline sD & & 14.5 & 3.4 & 12.9 & 5.64 & 5.80 & 0.84 & 0.79 & 0.30 & 0.23 \\
\hline \multicolumn{11}{|c|}{ Four normal subjects, $16 \mathrm{yr}$} \\
\hline Mean & & & & & 18.02 & 76.49 & 5.50 & 4.90 & 2.59 & 2.56 \\
\hline SD & & & & & 5.27 & 7.02 & 1.81 & 1.88 & 1.65 & 1.01 \\
\hline
\end{tabular}

Expected fat was calculated from height from the equations: males: fat $=12.116-0.215 \mathrm{ht}+0.00114 \mathrm{ht}^{2}$; ${ }^{1} \mathrm{SD}=3.84 \mathrm{~kg} ; \mathrm{N}=145 ; \quad$ females: fat $=27.514-0.538 \mathrm{ht}+0.00279 \mathrm{ht}^{2} ; \mathrm{sD}=3.43 \mathrm{~kg} ; \mathrm{N}=74$.

2 Excess fat $=$ total fat (from $\mathrm{D}_{2} \mathrm{O}$ )-expected fat.

${ }^{3} \mathrm{FFDS}=$ fat-free dry solid.

${ }^{4} \mathrm{NCP}=$ noncollagen protein. 
Table IV. Assessment of adipose tissue mass ${ }^{1}$

\begin{tabular}{lccc}
\hline Patients & $\begin{array}{c}\text { Adipose tissue mass }{ }^{2}, \\
\mathrm{~kg}\end{array}$ & $\begin{array}{c}\text { Collagen in adipose } \\
\text { mass }^{3}, \mathrm{~kg}\end{array}$ & $\begin{array}{c}\text { Noncollagen protein } \\
\text { in adipose } \text { mass }^{4}, \mathrm{~kg}^{2}\end{array}$ \\
\hline Obese male & 64.65 & 0.68 & 1.01 \\
Normal male $^{5}$, matched for height & 11.02 & 0.29 & 0.28 \\
Obese female $_{\text {Normal female }}^{5}$, matched for height & 41.49 & 0.29 & 0.45 \\
& 14.60 & 0.38 & 0.37 \\
\hline
\end{tabular}

1 Derived data, mean values.

${ }^{2}$ Adipose tissue mass $=\frac{\text { total fat }\left(\text { from } \mathrm{D}_{2} \mathrm{O}\right) \times 100}{\text { mean fat, } \% \text { in adipose tissue }}$.

${ }^{3}$ Collagen in adipose mass $=\frac{\text { adipose tissue mass } \times \text { collagen, } \%}{100}$.

${ }^{4}$ Noncollagen protein in adipose mass $=\frac{\text { adipose tissue mass } \times \text { noncollagen protein, } \%}{100}$.

${ }^{5}$ Calculated from expected fat and data from composition of adipose tissue in normal subjects (table III.)

strated in boys but no such increase was found in girls. One-half of the obese girls, including those with advanced bone age, however, had an increase in muscle mass relative to length while none of the boys showed this finding. Admittedly, few boys were studied and, therefore, one cannot be sure that findings for a larger group would be the same.

Patients with advanced bone age did not always have an early onset of obesity, although overgrowth of lean tissues was a frequent finding. Glassification of obesity into groups depending on these factors has not been possible in this study. Such a classification [16] would depend on assessment of fatness by ${ }^{40} \mathrm{~K}$ measurements, and ${ }^{40} \mathrm{~K}$ counting proved unreliable in the assessment of lean body mass in obesity, probably because of the large amount of peripheral adipose tissue that acted as a shield, reducing radiation from muscle and viscera. Forbes et al. [17] have proposed a correction factor that can be employed; however, body water measurements are reliable for the prediction of LBM in obesity $[1,29]$.

The observations on noncollagen protein in the adipose tissue mass support the contention that increments in the fat cell population are far more remarkable in the boy than in the girl. Since weight reduction is associated with diminution in fat cell size (rather than loss of cell number) [45] one would suspect that obese boys are placed at a greater disadvantage.

Excess growth of connective tissue in the male could be related to androgen or insulin production. In our previous work we found a remarkable increase in hydroxyproline excretion when androgens were given to patients with Turner's syndrome [10]. After maturity, androgens do not affect hydroxyproline excretion
[4]. Insulin causes growth of collagen even in the absence of the pituitary [12].

All obese girls with increments in nuclei population in muscle had advanced bone age. Bone maturation is related to thyroxin, estrogen, or androgen production and not to growth hormone [25]. Evidence from studies of rats indicates that estrogens are antagonistic to growth hormone and retard nuclei multiplication in muscle [9]. Thus, one might speculate that excretion of estrogens and androgens might be altered in some obese female patients. If such should prove to be the case, two classes of obesity in the female may exist, patients exhibiting excessive muscle growth and advanced maturation and patients without these characteristics.

It has been shown elsewhere [13] that number of nuclei in muscle correlates closely with chronological age in normal children and is thus a sensitive index of maturational age.

In addition to the possible role of androgens in the overgrowth of muscle, consideration also should be given to the action of growth hormone. Girls with excessive muscle growth relative to length resemble pituitary dwarfs receiving growth hormone, a situation in which muscle growth outstrips skeletal or linear growth and increments in number of nuclei are remarkable $[8,12]$. Injection of growth hormone into hypophysectomized rats produces multiplication of muscle nuclei and reduction of cell size [12]. By contrast, injection of insulin into the intact rat produces an increase in fatty tissue, and though there is growth of muscle mass, such growth is related to an increment in the protein/DNA ratio [21], and not to an increase in number of nuclei. Thus, it is possible that the over- 
growth of muscle in obese girls is related to the action of growth hormone. It was suggested earlier that overnutrition in infancy, either from high density feeding or high protein feeding, might program excess production of growth hormone and insulin in genetically susceptible infants [6].

Heald and Hunt [23] have shown that calorie restriction in obese adolescent boys prior to maturation produces a significant negative nitrogen balance when protein intake is maintained. Since increments in calorie intake appear to be related to increments in the number of cells in muscle [8] during adolescence in boys, and since growth hormone is important for cell number increase, it can be suggested that calorie restriction restricts growth hormone influence on muscle cells. Hence, a negative nitrogen balance might result. Both insulin and growth hormone are important for optimal amino acid uptake in muscle [34, 40, 49].

Adult patients with obesity have high circulating levels of insulin [38-40]. A similar situation holds for the obese adolescent [37]. The obese patient becomes increasingly insensitive to insulin [45] and, indeed, one of our patients with advanced bone age developed diabetes mellitus. Thus, the problem of obesity may well revolve around excess production and imbalance of hormones which, as suggested elsewhere [13], may be reflected in the pattern of cell size and population of nuclei in muscle.

As to what extent heredity, a diabetic diathesis, and overnutrition are involved remain questions to be resolved by future research. The observations of Rose and MAYER [44] concerning physical inactivity in fat infants early in postnatal life underlines the importance of heredity. The four patients in our study with no family history of obesity had late onset of obesity (5-7 years). If overnutrition is responsible for advanced maturation and overgrowth in experimental animals $[15,50]$, the possibility exists that one class of obesity is more directly related to environmental factors. Close inspection of birth weights in a large group of obese girls might provide a clue, since among obese girls only one with advanced maturation had excess birth weight $\left(\mathrm{O}_{50}\right)$. This patient had no family history of obesity and the onset of obesity occurred at 5 years of age. Thus, the balance of our limited evidence suggests that advanced maturation in obese girls depends on environmental as well as on genetic factors.

\section{Summary}

Fourteen obese females and nine obese males were investigated. Body water and body fat, extracellular and intracellular volume (and intracellular mass) were determined together with bone age, body length, and body weight. 'Expected fat' was calculated from length and subtracted from total fat to yield 'excess fat'. Adipose tissue samples were analyzed for major constituents and the content of collagen and noncollagen protein calculated within the adipose tissue mass. Muscle mass was determined from excretion of creatinine and a sample of muscle was taken for estimation of size and number of muscle cells. The total number of nuclei in muscle was calculated.

The majority of patients showed excessive length and excess fat (15-89 kg for boys and 9-45 kg for girls). The assessment of excess tissue growth was based on body length. Lean body mass and intracellular mass were increased for nearly all patients.

Boys showed no evidence of increased muscle mass for length but did have excess collagen and protein in the total adipose mass.

Girls showed little evidence of increased lean tissue within the adipose mass but one-half of the female patients had an increase in muscle mass and five of these seven also had advanced bone age, an increased nuclei population, and reduced protein/DNA ratio in muscle.

\section{References and $\mathcal{N}$ otes}

1. Babineau, L.M. and Page, E.: On body fat and body water in rats. Canad.J. Biochem. 33: 970 (1955).

2. BAKer, G.L.: Human adipose tissue composition and age. Amer.J.clin. Nutr. 22: 829 (1969).

3. Battaglia, F. G. and Lubchenco, L.O.: A practical classification of infants by weight and gestational age. J. Pediat. 71: 159 (1967).

4. Benoit, F.L.; Theil, G.B. and Watten, R.H.: Hydroxyproline excretion in endocrine disease. Metabolism 12: 1072 (1963).

5. Canning, H. and Mayer, J.: Obesity-its possible effect on college acceptance. New Engl.J.Med. 275: 1172 (1966).

6. Cheex, D. B.: Conclusions and future implications; in: D. B. GHeEk : Human growth, chapt. 43, p. 616 (Lea \& Febiger, Philadelphia 1968).

7. Gheek, D.B.: Human growth (Lea \& Febiger, Philadelphia 1968).

8. Cheek, D. B. : Cellular growth hormone, nutrition, and time: Borden award address, October 1967. Pediatrics 41: 30 (1968).

9. Cheek, D. B. ; Brasel, J. A. and Graystone, J. E. : Muscle cell growth in rodents: Sex difference and the role of hormones; in: D.B. Cheex: Human growth, chapt.22, p. 306 (Lea \& Febiger, Philadelphia 1968).

10. Cheek, D.B. and Graystone, J.E.: Connective tissue growth. Part I. Hydroxyproline excretion; 
in: D. B. CheEK: Human growth, chapt. 15, p.221 (Lea \& Febiger, Philadelphia 1968).

11. Cheek, D.B. and Graystone, J.E.: Intracellular and extracellular volume (and sodium) and exchangeable chloride in children; in: D. B. CHEEK : Human growth, chapt. 10, p. 150 (Lea \& Febiger, Philadelphia 1968).

12. Cheek, D.B. and Graystone, J.E.: The action of insulin, growth hormone, and epinephrine on cell growth in liver, muscle, and brain of the hypophysectomized rat. Pediat. Res. 3: 77 (1969).

13. Cheek, D.B. and Hrll, D.E.: Muscle and liver cell growth: Role of hormones and nutritional factors, calories, protein, and zinc. Fed. Proc. (in press).

14. Cheek, D.B. and Holt, A.B.: Growth and body composition of the mouse. Amer. J. Physiol. 205: 913 (1963).

15. Filer, L.J. and Churella, H.: Relationship of body composition, chemical maturation, homeostasis and diet in the newborn mammals. Ann. N.Y. Acad. Sci. 110: 380 (1963).

16. Forbes, G. B.: Toward a new dimension in human growth. Pediatrics 36: 825 (1965).

17. Forbes, G.B.; Schultz, F.; Cafarelly, G. and Amirhakimi, G.H.: Effects of body size on potassium-40 measurement in the whole body counter (tilt-chair technique). Health Physics 15: 435 (1968).

18. Garn, S.M.; Rohmann, G.G. and Silverman, F.N.: Radiographic standards for postnatal ossification and tooth calcification. Med.Radiogr. Photogr. 43: 44 (1967).

19. Garn, S.M. and Young, R.W.: Concurrent fat loss and fat gain. Amer.J.phys. Anthrop. 14: 497 (1956).

20. Graystone, J.E.: Creatinine excretion during growth; in: D. B. CHeEk: Human growth, chapt. 12, p. 182 (Lea \& Febiger, Philadelphia 1968).

21. Graystone, J.E. and Gheek, D.B.: The effects of reduced caloric intake and increased insulin-induced caloric intake on the cell growth of muscle, liver, and cerebrum and on skeletal collagen in the postweanling rat. Pediat. Res. 3: 66 (1969).

22. Greulich, W.W. and Pyle, S.I.: Radiographic atlas of skeletal development of the hand and wrist (Stanford University Press, Stanford 1959).

23. Heald, F. P. and Hunt, S. M.: Caloric dependency in obese adolescents as affected by degree of maturation. J. Pediat. 66: 1035 (1965).

24. Heald, F. P.; Hunt, E. E.; Schwartz, R.; Cooke, C.D.; Elliott, O. and VAjDa, B.: Measures of body fat and hydration in adolescent boys. Pediatrics 31: 226 (1963).

25. Hubble, D.: Disorders of growth; in: D. GairdNER: Recent advances in pediatrics, 3rd ed. (Ghurchill, London 1964).
26. Huenemann, R.L.; Shapiro, L.R.; Hampton, M.C. and Mrtchell, B.W.: A longitudinal study of gross body composition and body conformation and their association with food and activity in a teen-age population: Views of teen-age subjects on body composition, food and activity. Amer.J. clin. Nutr. 18: 325 (1966).

27. Johnson, M.L.; Burke, B.S. and MAyer, J.: Incidence and prevalence of obesity in a section of school children in the Boston area. Amer.J.clin. Nutr. 4: 231 (1956).

28. KnItTle, J.L. and HrRsch, J.: Effects of early nutrition on the development of rat epididymal fat pads: Cellularity and metabolism. J. clin. Invest. 47: 2091 (1968).

29. LjungGren, H.: Studies on body composition: With special reference to the composition of obesity tissue and non-obesity tissue. Acta endocrin., Kbh. suppl. 33 25: 1 (1957).

30. Lloyd, J.K.; WolfF, O.H. and Whelen, W.S.: Childhood obesity; long-term study of height and weight. Brit.med.J. 2: 145 (1961).

31. Lowry, O.H.; Gilligan, D.R. and Katersky, E.M.: The determination of collagen and elastin in tissues, with results obtained in various normal tissues from different species. J. biol. Chem. 139: 795 (1941).

32. Mellits, E.D. and Cheek, D.B.: Growth and body water; in: D.B. CheEk: Human growth, chapt.9, p.135 (Lea \& Febiger, Philadelphia 1968).

33. Mellits, E.D. and Cheek, D. B.: The assessment of body water and fatness from infancy to adulthood. Monogr.Soc. Res. Child Develop. Presented at the International Anthropological Congress, Kyoto, September 1968 (in press).

34. Munro, H.N.; Black, J.G. and Thomson, W.S.: The mode of action of dietary carbohydrate on protein metabolism. Brit. J. Nutr. 13: 475 (1959).

35. Nicholson, J.P. and Zilva, J.: Body constituents and functions in relation to height and weight. Clin. Sci. 27: 97 (1964).

36. Pariskova, J. and Vamberova, M.: Body composition as a criterion of the suitability of reducing regimens in obese children. Develop.med. Child Neurol. 9: 202 (1967).

37. Paulsen, E. P.; Richenderfer, L. and GinsbergFellner, F.: Plasma glucose, free fatty acids, and immunoreactive insulin in sixty-six obese children. Studies in reference to a family history of diabetes mellitus. Diabetes 17: 261 (1968).

38. Perley, M. and Kipnis, D.M.: Plasma insulin responses to glucose and tolbutamide of normal weight and obese diabetic and non-diabetic subjects. Diabetes 15: 867 (1966). 
39. Rabinowitz, D.; Merimee, T.J.; Nelson, J.K.; Schultz, R. B. and Riggs, L.: The hormonal profile in obesity. Trans. ass. amer. Physicians 80: 190 (1967).

40. Rabinowitz, D. and ZrerLeR, K.L.: Forearm metabolism in obesity and its response to intraarterial insulin. Characterization of insulin resistance and evidence for adaptative hyperinsulinism. J.clin. Invest. 41: 2173 (1962).

41. Rauh, J.L.; Schumsky, D.A. and WitT, M.T.: Heights, weights, and obesity in urban school children. Child. Develop. 38: 515 (1967).

42. Reba, R. G.; Leitnaker, F.C. and Woodward, K.T.: Determination of total body potassium by measurement of ${ }^{40} \mathrm{~K}$; in: D. B. CHeEk: Human growth, chapt. 45, part II, p.674 (Lea \& Febiger, Philadelphia 1968).

43. Reynolds, E. L.: The distribution of subcutaneous fat in childhood and adolescence. Monogr. Soc. Res. Child Develop. 15: 2 (1951).

44. Rose, H.E. and Mayer, J.: Activity, calorie intake, fat storage, and the energy balance of infants. Pediatrics 41: 18 (1968).

45. Salans, L. B.; Knitrle, J. L. and Hirsch, J.: The role of adipose cell size and adipose tissue insulin sensitivity in the carbohydrate intolerance of human obesity. J. clin. Invest. 47: 153 (1968).

46. Stefanik, P.A.; Heald, F.P. and Mayer, J.: Caloric intake in relation to energy output of nonobese and obese adolescent boys. Amer.J. clin. Nutr. 7: 55 (1959).

47. Talbert, J.L. and Haller, A.: Tissue analysis. Part I. Muscle biopsy technique in infants and children; in: D. B. CheEK: Human growth, chapt. 44, p. 649 (Lea \& Febiger, Philadelphia 1968).
48. TANner, J. M. and Whrtehouse, R. H.: Measurement of skinfold thickness in childhood. Committee on Nutrition. Pediatrics 45: 538 (1968).

49. WAgle, S.R.: The influence of GH, cortisol and insulin on the incorporation of amino acids into protein. Arch. Biochem. 102: 373 (1963).

50. Widdowson, E.M. and MaGance, R. A.: Some effects on accelerating growth. I. General somatic development. Proc.roy. Soc. B. 152: 188 (1960).

51. Winick, M. and Noble, A.: Cellular response with increased feeding in neonatal rats. J. Nutr. 91: 179 (1967).

52. We are grateful to John P. Dorst, M.D., for assessment of bone age in these patients and to JOAN E. Graystone, M.Sc., for assistance in the early stages of this work. We also thank Lt. EARLE Scrom, USN, National Naval Medical Center for his collaboration and assistance with the ${ }^{40} \mathrm{~K}$ estimations. Thanks are due to Dr. John White for assistance with biopsy procedures.

53. Informed consent was obtained for all subjects in this study.

54. Support for Dr. Adalberto Parra was provided by National Institutes of Health International Postdoctoral Research Fellowship no.1F05 TW 1400-01.

55. Supported by Public Health Service Research Grant no. HD 00126-06 from NICHD. Work on ${ }^{40} \mathrm{~K}$ was supported by the Division of Radiological Sciences, The Johns Hopkins Hospital Grant no. GM 10548.

56. Requests for reprints should be addressed to: D.B. Chenk, M.D., The Johns Hopkins Hospital, 601 N. Broadway, Baltimore, MD 21205, USA.

57. Accepted for publication October 9, 1969. 